\title{
A MODEL OF LATER NINETEENTH CENTURY EUROPEAN ECONOMIC DEVELOPMENT**
}

\author{
JAMES FOREMAN-PECK \\ St. Antony's College, Oxford
}

\section{RESUMEN}

En este trabajo se desarrolla y estima un modelo para explicar los motivos por los cuales algunos países europeos prosperaron más rápidamente que otros en el período 18601910. El modelo cuantifica por dos vías distintas los factores que contribuyeron a las diferencias de ingreso entre España y Gran Bretaña. Los determinantes que se consideran más significativos son los recursos naturales, la política económica y la herencia cultural reflejada en los niveles educativos.

\section{ABSTRACT}

A model is developed and estimated to explain why some European countries were richer than others between 1860 and 1910 and why some increased their prosperity faster in the period. The model quantifies by two methods some of the contributors to the income gap between the economies of Spain and Britain in 1880 and 1910. Determinants of European nations' output per head included natural endowments (climate and coal deposits), economic policy (tariff protection and very marginally the gold standard), and cultural heritage as reflected in literacy. Measurement errors, country specific factors and perhaps variables not considered in this analysis account for less than half Spanish-UK income differences at the dates estimated.

Financial assistance from the Nuffield Foundation is gratefully acknowledged. Earlier version of this paper were given as a lecture at the Instituto Mori, Mexico City, July 1992 and at the European Historical Economics conference on "Long Term Economic Growth in the European Periphery" at Pazo de Marinan July 1993, the Social Science History Association meeting at Baltimore 1993, and seminars at Reading, Oxford and Exeter. I have taken advantage of the discussion with participants, and of the comments of others who may prefer to remain anonymous, to improve this version. 
By the later nineteenth century, European economies were clearly embarked on a period of sustained economic development. National outputs per head all rose, albeit at different rates and from various levels. Distinctive languages, cultures and institutions favoured clear national identities. On the other hand freedom of movement of people, ideas and goods across frontiers, coupled with radically improved transport and communications facilities, encouraged a convergence of national economies. The gold standard and the most favoured nation clause, together with the railway, the steamship and the telegraph, were the nineteenth century framework for the rapid diffusion of economic development. European economies were therefore likely to share a similar pattern of change and growth. That is the precondition for modelling their nineteenth century development. In this present attempt to do so, the central questions are why some European countries were richer than others between 1860 and 1910 and why some increased their prosperity faster in the period. A satisfactory model would answer these questions. In particular the model should show what characteristics contributed to income gaps, such as that between the economies of Spain and Britain. Even if existing estimates of real national product per head are only approximately correct, the variations to be explained are substantial; in 1860 the wealthiest country was more than three times richer than the poorest in the sample analysed here and in 1910 the gap had widened to four times'.

Section I gives a selective four part summary of the literature which the proposed model of European economic development is intended to illuminate. Section II identifies the most fundamental terms of an economic historical explanation for development and goes on to classify the possible endogenous variable set. The third section then specifies the model and describes the data on which it is tested and from which the parameters are estimated. The results and their implications are reported in section IV.

\section{THE HISTORIOGRAPHIC BACKGROUND}

Comparative European economic history that explains, as well as describes, events and outcomes, requires some theory. One event may follow or be associated

Lains' (1992) examination of the reliability of GDP estimates for 1913 shows a similar range of variation in that year. The widening gap is probably a consequence of the increasing range of countries in the sample. In the early years of the period few estimates for the low income economies were available. Thus although the gap had persisted for many earlier decade, it was only in 1906 that Prokopovitch began a vigorous debate on Russian economic performance with his claim that English income per head was four and a half times Russia's (Studenski (1958), p. 145-6). Gregory's (1982) figures suggest Russian real national income per head grew by 60 per cent $1860-1910$, but stagnated for the first thirty years. The British growth figure was very similar. So the Russian-UK gap had probably been greater in the 1870 s. 
with another but a causal connection cannot be inferred without some prior, necessary, link between them. Otherwise the association may be merely a matter of chance. Even when the historian is armed with theoretical reasons for connections, magnitudes and relative contributions cannot usually be inferred. That requires quantification of variables and of relationships between them. The cumulative efforts of researchers now permit tentative steps in this direction and, in taking them, the testing of previous conjectures and hypotheses.

One of the earliest supposed explanations for European economic development in the nineteenth century was in fact description (not necessarily accurate); the 'leader and follower' scheme. In this account Britain experienced the first industrial revolution which boosted her productivity in manufacturing and income above those in the rest of Europe, and then, with varying alacrity, other European economies adopted similar technology and work organisation. The pace at which they did so determined the lag in real income behind Britain. Keywords in this representation, associated in particular with Rostow (1960), Landes (1970), Pollard (1981), Gerschenkron (1966), are 'discontinuity', 'diffusion' and 'backwardness' (O'Brien 1986) ${ }^{2}$. Explanations for income differences should then turn on the determinants of the speed of adoption, but that was not usually discussed in any detail. Since it was widely assumed the new technology could only be adopted if more capital was available, growth models of the 1950 s and 1960 s encouraged and reflected this approach to economic development by assigning a central place to capital accumulation, savings ratios and 'traverses' between long run equilibrium growth paths.

What undermined these conceptions was the quantification of European economic development that was proceeding simultaneously. Subsequent empirical research has proved mythical 'discontinuities', 'take-offs' or 'great spurts' in national European economic development. Higher shares of production goods in the output of more backward countries, larger plant scale, greater roles for investment banks and diminished contributions from agriculture, have been shown equally chimerical (Milward and Saul (1973), (1977)); Sylla and Toniolo (1991). The big leap in capital accumulation actually was necessitated not by manufacturing but by infrastructure, in particular by railways, which in Britain accounted for a far higher proportion of the capital stock than manufacturing until the interwar years (Feinstein and Pollard 1988).

During the later 1970 s, the 'alternative roads' school began to erode the 'leaders and followers' approach. The numbers suggested that Britain was different and that other paths to development could be, and were, taken. The French did GDP.

${ }^{2}$ Gerschenkron's representation focussed on industrial production whereas Rostow referred to 
not lag behind British economy as far as had previously been thought and managed to avoid some of the problems of urbanisation for industrial development (O'Brien and Keyder 1978). Britain's great emphasis on coal was unusual throughout the period (Crafts 1984). Though coal was a determinant of the possibilities for later nineteenth century economic growth, human capital could be a substitute input. It allowed rapid development, even without indigenous coal deposits, especially in Scandinavia, based upon advanced industrial sectors that Britain tended to neglect (Sandberg 1982; Cameron 1985) ${ }^{3}$. Most ambitious among those who have plotted alternative patterns of development for the years 1850 to 1914 are Morris and Adelman (1988). In addition to European countries their sample includes Japan, four "very poor" countries, two Latin American economies and four countries of recent European settlement. With the help of 35 criteria for each country and principal components analysis, they find five development paths; two industial, two agricultural and one "balanced". But the selection of indicators is somewhat res-
tricted and arbitrary.

A third group of writers largely rejected formal quantitative methods imported from economics. Following traditional economic history, they emphasized the role Europe as a whole, they did consider concepts relevant to long term European economic development. Chandler (1990) addressed British and German business development in relation to the United States, Elbaum and Lazonick (1986) restricted themselves among European countries to Britain, North (1981) used Europe, in a comparative perspective.

Political institutions are identified as the key to economic development with remarkable unanimity by authors of recent general economic histories that include Europe in their coverage. Rosenberg and Birdzell's (1986) short answer to the maintaining that accumulation of wealth, both individually and collectively, is a strong and universal human propensity, answer that government did not get in the way too much in the West, either by wars and invasions or by regulation and taxation, thanks to a fairly wide dispersion of political power. Cameron (1989) takes a similar tack, agreeing on the primacy of the state in creating favourable conditions.

\footnotetext{
'On the other hand subsequent revision of Swedish national income estimates has cast doubt on
the extent to which Sweden was poor in the nineteenth century and thus suggest Sweden's high literacy
created high income in an earlier period. See Krantz (1988).
} 
He asserts that states controlled by mercantile interests were those that pursued the most appropriate policies.

Kennedy (1987) contended that the peculiarities of the London capital market distorted British economic development. All these 'new institutionalist' authors, offer plausible accounts but the demonstrations of their propositions are not rigorous. Thus from an industry by industry analysis, Chandler maintains that Britain's failure to develop large integrated firms with professional managerial hierarchies from 1880, unlike the US and to a lesser extent Germany, explained British inability to hold her economic lead. Adopting a similar approach to Chandler's, that hypothesis can be tested by considering whether all US world class firms were organised in professional managerial hierarchies. Ford until the 1930s is a counterexample. Before 1914, Ford foremen were able to hire and fire and until the 1920s the company was run as a family business following the founders' precepts, rather than those based on rational professional analysis (Wilkins and Hills 1964; Meyer 1981). Yet for much of the first quarter of the century Ford dominated the world motor industry primarily because of the ability to gain economies of scale and learning, by supplying the US farm market.

Managerial hierarchies in which Britain, and most of the rest of Europe were deficient, were not essential for success. Inertia in the face of a changing economic environment plausibly explains a part of the interwar decline of Britain's cotton industry and more generally may well be a factor preventing the optimum adjustment of market institutions (as Lazonick has consistently maintained). But that does not tell us how much of differential real income levels in Europe should be attributed to this influence.

Olson's no less plausible theory of distributional coalitions suffers from the same drawbacks. Within national economies, these coalitions supposedly become stronger and more pervasive with the passage of time and in the absence of shocks. They redistribute income towards themselves, and in so doing, slow economic development. Much of 19 th century European history does not easily square with Olson's account. The formation of the Zollverein in 1834 may have been a salutary economic shock for Germany, but the unification of Italy does not appear to have worked a similar miracle. France regularly experienced political upheavals while Britain's constitutional change was a comparatively tranquil affair, yet France did not match British income per head. Spain, with 58 governments and 83 ministers of public finance between 1868 and 1915 (Platt 1984, p. 107), was racked by war and unstable governments. These shocks to Spain were not obviously benign influences on long run growth.

What is needed is some estimate of the pervasiveness and effects of Olson's "sclerotic institutions". Pencavel's (1977) calculation of the effects of British unio- 
nisation of the coal industry on productivity in the first decade of the twentieth century is supported by a plausible model that fits the data, but the example shows one of the roles of quantification; despite such institutional sclerosis British income and productivity was generally higher than elsewhere in Europe. Olson's scheme may well have considerable explanatory power without addressing the reasons for differences between European countries and over time in incomes per head.

A variation on the 'new institutionalism' theme is 'path dependence' or 'nonergodic growth'; a (unique) event, policy or institution (or random shock) in one period changes the state of an economy permanently in the following period. Growth, then, is largely determined by events and institutions in previous periods. If this is so it might seem that no general explanation of economic growth is possible. But still generalisations may be appropriate for particular regions and epochs. In practice the concept can degenerate to one of the most primitive, though plausible, types of historical explanation, 'post hoc ergo propter hoc'. In the absence of theory, causal ordering is inferred from temporal order. Temporal order does of course contain information about causal ordering because (at least ignoring expectations) the arrow of time only flies in one direction ${ }^{4}$. A possible example of path dependence is the traditional interpretation of nineteenth century French economic development which suggests the strong adverse influence of the redistribution of land during the French Revolution (Caron 1979 p. 37). The more egalitarian income distribution and electorally significant numbers in agriculture supposedly encouraged savings patterns and state policies less conducive to industrial growth
in France than in Britain. How much can be attributed to these (economically) con-
tingent conditions can be judged from Levy-Leboyen tingent conditions can be judged from Levy-Leboyer and Bourguignon's (1990) econometric model. The answer seems to be 'not much'; agriculture was apparently growth between 1825 and 1859 (Levy-Leboyer and Bourguignon 1990, p. 226). In this instance quantification hints at a rather different path dependence from con-
ventional accounts.

Harking back to the earlier literature on European development, recent empirical economic analyses of growth experience for developed countries have been stimulated by a new wave of modelling initiated by Baumol's (1986) attempt to show
that there had been a general tendency to convergence since 1870 among GNPs
per head of industrial countries. Baumol's thesis per head of industrial countries. Baumol's thesis was that the US productivity slow down of the 1980 s was part of the natural order. An earlier phase of modelling by an inability to take advantage of the productivity gains from reallocating resour-
.

4 An observation on which the econometrics of Granger causality places great weight. 
ces from agriculture to industry, because the redistribution had already taken place. This sectoral distinction is at the heart of Arthur Lewis' model of economic development with unlimite supplies of labour. That model formed the basis of many subsequent analyses of economic growth in poorer countries and Kindleberger (1964) has argued that it is a means of understanding Western European development over a longer period. Only Levy-Leboyer and Bourgignon's dual economy model has taken up the suggestion for the nineteenth century.

Most recent models explain the rate of economic growth or the level of income by mean of cross-section regression of national data; sometimes pooled with time series. Extending Baumol's sample beyond the data available in Maddison (1982), in particular including economies such as Argentine and Chile (high income countries in the nineteenth century with poor twentieth century development records), called into question any tendency for general convergence (De Long 1988). Weber's thesis has also risen again with a regression showing that whether a country was predominantly Protestant determined whether or not it joined the high income 'club' (De Long 1988). The post- 1960 period has been subject to the most intensive analysis. An aggregate production function with 'catch up' terms explains a significant proportion of intercountry variation in average growth rates over these years (Dowrick 1992). There is some reason to suppose that the ability of countries to take advantage of backwarness depended on infrastructure and on population growth. Those economies not showing signs of convergence experienced high population growth and therefore high ratios of young dependants to the total work force. Disaggregation into industry and agricultural sectors, revealed substantial intersectorial differences in technical progress, and disequilibrium in factor markets (Dowrick and Gemmel 1991). Once school enrolment rates (a proxy for human capital) were taken into account in a sample of 98 countries between 1960 and 1985, growth rates were negatively related to the initial level of 1960 real GDP per head, as convergence requires (Barro 1991).

Theoretical 'support' for the convergence hypothesis lagged behind empirical analysis but eventually models with convergence explicitly derived from a neoclassical growth model were estimated (Barro and Sala-i-Martin 1992; Mankiw Romer and Weil 1993). This model assumes the existence of markets that are allowed to adjust to changes external to the model. Hence the likelihood is that among the more fundamental conditions that made 'catching up' a possibility after 1960 (and after 1945), was the 'Bretton Woods' regime of fairly liberal trade and monetary relations. This was conducive to the diffusion of techniques just as was the gold standard period before 1914. In Europe, openness to other European trading partners and to rest of the world by 1914 had in many cases reached levels comparable to those after 1960 . National price changes were not widely dispersed, especially bearing in mind the limitations and comparability of the available index 
numbers, and intra-European labour flows were substantial; there were more Italian and Belgian workers in France in 1911 than in 1982, if official statistics are to be believed. The similarity between the conditions under liberal gold standard regime and those of the Bretton Woods system and later modifications presents a prima facie case therefore that, data permitting, comparable methods of analysis to those employed for the post 1960 years may be appropriate for Europe between 1860 and 1914.

\section{THE KEY VARIABLES IN EUROPEAN DEVELOPMENT}

However a good deal of empirical economics is concerned with testing models 'received' from theory and these are not necessarily ideally adapted for historical explanation. The factors and parameters of the neoclassical production function - the level of human and physical capital, the fertility of the soil, and perhaps also the size of the labour force, and the adoption of technology- themselves need explaining. Explanation must then be pushed back to what determines factor supplies and production parameters.

The first stage of modelling then is to identify the relevant variables. Figure 1 is a classification of the most general causes of economic growth into exogenous and endogenous sets. Technology is at least predetermined, for what can be achieved in a given period is largely dependent upon earlier progress in related technologies. Even such an apparently low-technology development as the safety bicycle of the 1880s depended upon prior metallurgical development in light but strong tubing and for chain links, in (wheel) bearings, in rubber and in pneumatic tyres 5 . Technology is however embodied in capital, which is certainly an endogenous variable, and to some extent can be advanced by research and development expenditure. Moreover it is extremely difficult to represent in an abstract summary fashion other than through the production function. Assuming rapid diffusion of technical knowledge among European economies, we can treat the most abstract notion of technology as a common element across countries, and embodied in capital with the passage of time. Possibly a difference from American technology was that the European variety, if one existed, was less natural resource-intensive, was directed to smaller markets and was more skill-intensive and so capital-saving (Nelson and Wright 1992). But here we are concerned only with intra- European technology differences.

"The limitations of the "Odinary" or "Penny-farthing" show just how necessary these advances were- the tendency of front wheel bearings to seize at speed, throwing the rider over the handlebars, and
the athletic prowess necessary even to get into the saddle. 


\section{FIGURE 1}

Key Variables in Nineteenth Century European Economic Development

EXOGENOUS

Technology

Natural Resources

Regime

Culture/Religion

Institutions

topography

climate

coal

taxation

tariffs

monetary

policy

war

state

ownership

ENDOGENOUS

Physical Capital

railways...

Human Capital

literacy
Demography

Industrial Structure

agriculture

Real GNP per head

Natural resources in the form of coal deposits are one possible explanation for the pattern of European development in the nineteenth century, determining the availability of power and heat for transport and industrial processes (Cameron 1985). Abundant coal supposedly allowed precocious development. Trade may or may not have compensated for differential coal endowments. Even within countries location could be a vital influence upon coal prices. Just before the opening of the period of study, in England of 1843 coal prices in the dearest counties were five times those of the cheapest (Crafts 1985, p. 68). Jevons (1906) contended that the price advantage of British coal in the 1860 s had been lost to Pennsylvania and matched by Germany by the end of the century. His data show France paying one third more than her coal-endowed European competitors.

Climate is a more neglected natural resource (with the recent exception of Tortella (1994)). The properties of the soil are strongly influenced by the way it is cropped, irrigated or drained. But rainfall and temperature at different times of the year is an almost entirely natural endowment which determines agricultural productivity, corresponding to the classical definition of the factor land. Where rainfall is concentrated in a small number of days, as in Southern Europe, when torrential rain is followed by drougth, moisture evaporates in a few hours. Where, as in Northern Europe, more rainfall over more days with lower temperatures maintains soil moisture, alfafa, ryegrass and clover grow thick and rich. Cows, sheep and draught animals flourish on such a diet. Hence climate is a determinant of the animals to land ratio that Slicher van Bath (1963) and O'Brien and Keyder (1978) have emphasized as underlying high crop yields. Soil quality is not merely a natural resource; it can be depleted or accumulated by agricultural investment. Hot dry 
summers impose a cost in the form of investment in irrigation. On the other hand higher temperatures alone may allow a greater cash yield per acre. Irrigation and drainage, crop mixes and fertilisers can substitute for nature's deficiencies but not at zero cost. Countries with more favourable climates still possess an agricultural productivity advantage ${ }^{6}$.

Most abstract among the more obvious pre-determining variables are culture and religion. Max Weber's thesis that the rational spirit of protestantism encouraged capitalism found some support from De Long's 'Protestantism' regression, but a more systematic index would be desirable. There is some French evidence that the nineteenth century development of religious practices may have influenced the acquisition of reading skills (Caron 1979). Much later, Protestants in France achieved far higher proportions of top managerial and professional jobs than their minority representation in the French population warranted (Yoshimuri 1988). That is consistent with the hypotheses discussed here but in the absence of more general developments in comparative quantitative religious or cultural history, the presumed consequences of these factors must be employed as potential 'ultimate' -or exogenous- explanations instead.

Quantification of political regimes is easier in some respects than religion and culture. The taxation they impose - both levels and forms-, their propensity to wage war, their monetary arrangements, can be statistically summarised and compared across economies. However the different delegations of taxation below central government in practice means that readily available data is likely to measure the degree of federalism as much as the weight of taxation. Included in regimes, and closely related to taxation, government spending, and the political constitution, is the monetary order. Countries unable to balance their budgest were liable to use fiat currencies or currencies at a discount to their nominal metallic values. Even those countries which maintained metallic links were not immune from monetary disorder and the consequent adverse impact on business. Both silver and bimetallic currencies were in difficulties because of changing relative prices of gold and silver from the mid-century. Turning to purely political measures, a genuine measure of democracy in principle may be possible also, though requiring considerable work. Much more problematic is the quantification of differences in institutions across Europe. Much of this variation must be ascribed to unique, country-specific, influences on growth.

That completes the list of non-economic variables in abstract that are exogenous to an economic model of economic development ${ }^{i}$. First among the obvious

- I am grateful to Francesco Galassi for discussion and correspondence on these points.

That is not necessarily the same as being actually exogenous. The list is not exhausted for a
general political or social model. 
endogenous, or more proximate, variables is physical capital; higher income economies create, or have had created for them, more capital. In the later nineteenth century, apart from land and buildings, that meant primarily railways. Capital also embodied new techniques, or rather gross investment in any period did. The second form of produced factor of production is human capital; the education, training, skills and traits embodied in the work force. As already discussed, national values of the variables reflect institutional and cultural influences which must remain implicit or residual, and exogenous in this, but not necessarily in later, analyses.

The structure of industry is yet another endogenous variable, determined by the growth process; with rising incomes the pattern of demand changes and as part of the supply response, resources flow to new places of work and activity. These may vary in their productivity potential and so in their contribution to economic development. The dual economy, with an advanced and a traditional sector may be a consequence and a cause of later nineteenth century European economic growth.

\section{MODEL STRUCTURE AND EUROPEAN CHARACTERISTICS}

Assessing whether there was a common development process across European countries and over time can be tested by estimating the $a_{i}$ parameters for the model in Figure 2. A typology aims to predict (but not explain) the characteristic mix $\sum \mathrm{a}_{\mathrm{i}} \mathrm{X}_{\mathrm{i}}$ from given values of $\mathrm{Y}$, the level of real income per head or development (Chenery and Syrquin 1975; Crafts 1984; Molinas and Prados 1989), while a model predicts $Y_{i}$ from values of $X$. By contrast with a typology, if a causal pattern is identified then it will support counterfactuals; the values of the parameters will not change when the explanatory variables alter, either in history or in a thought experiment.

The relationships in Figure 2 are of two types. They may represent behaviour directly, such a labour supply equation, in which case they are structural. Structural equations are the building blocks of a complete explanation. Alternatively the relationships of Figure 2 summarise the impact of explanatory influences determined outside the model (exogenous) on the (endogenous) variable to be explained; they are reduced form equations. Reduced form equations show the effect of the exogenous variables upon the endogenous variable set. They are not full explanations in themeselves, for they do not explicitly include the mutual interaction of endogenous variables in the structural equations.

The historian observes or creates a set of data from which an explanation is constructed. In principle both structural and reduced form relationships can be fitted 
FIGURE 2

A Scheme for Explaining Late Nineteenth Century European Development

Real GNP per head

$Y_{i}$

pan-European explanatory variables

$X_{i j}$

Country 1 at beginning of decade 1

$Y_{1}=a_{1} X_{11}+a_{2} X_{12}+\ldots+e_{1}$

national peculiarities, policies, events, institutions and measurement errors

Country 2 at decade 1 or country 1 at decade 2

$$
\begin{aligned}
& Y_{2}=a_{1} X_{21}+a_{2} X_{22}+\ldots+e_{2} \\
& Y_{3}=a_{1} X_{31}+\ldots+e_{3} \\
& \longleftarrow \text { causation typology } \longrightarrow
\end{aligned}
$$

Structural equations; $Y=f(Z), Z=g(X)$, where $Z_{5}$ are intermediate variables or reduced forms; $Y=h(X)$.

to the data to represent the explanations formally. But although there may be a unique reduced form equation that fits the data best, a number of alternative structural relations might nevertheless be encompassed by the same reduced form; a variety of explanations can be consistent with the same body of evidence (observational equivalence). Supposing a reduced form indicates that coal availability influenced European nineteenth century GDP, we may still want to know the channels by which it did so, whether directly through manufacturing consumer goods or indirectly through lowering the costs of capital goods and transport. These channels are represented by structural equations. Whether structural parameters can be inferred from the reduced form is the identification problem. If we are only interested in 'retrodiction', forecasting what would have happened had the exogenous values been different, without explaining, then we need pay no attention to the structural relations and their identification, unless to seek confirmation that the reduced form is correct.

Gerschenkron's notion of substitute for alleged preconditions of European nineteenth century development draws attention to the variety of different values of $\mathrm{X}_{\mathrm{ij}}$ that are compatible with a given value of $\mathrm{Y}$ in Figure 2 . In this framework sufficient conditions are easier to model than necessary". Backwardness or "catching

${ }^{*}$ Even such a simple model can be used to expose the weakness of Weber's $(1961, \mathrm{pp} .258-60)$ demonstration of the causes of the rise of capitalism. His argument has the form; $X 1, \ldots X 4$ are all asso. ciated with $Y$ in the West, but we can find cases where $X 1 \ldots X 3$ are not associated with $Y^{\prime}$ elsewhere. Therefore $X 4$ must be the cause. It was not population growth (X1) because population grew in China without having that effect, it was not the inflow of precious metal from the New World (X2) because a 
up' as a positive influence on the potential for raising income $(Y)$ can be represented by a term $Y_{i} / Y_{i}$, or $Y_{i}-Y_{i}$, where $Y_{i}$ is the GNP per head of the follower country. But then what is to be explained, $Y_{i}$, is also part of the explanation. This can be seen from equation (1) describing the aim of the paper; to explain why some countries $\left(\mathrm{Y}_{\mathrm{i}}\right)$ were richer than others $\left(\mathrm{Y}_{\mathrm{j}}\right)$ in later nineteenth century Europe.

$$
Y_{i}-Y_{j}=a_{1}\left(X_{1 i}-X_{1 j}\right)+a_{2}\left(X_{2 i}-X_{2 j}\right)+\ldots+\left(e_{i}-e_{j}\right)(1)
$$

In the present scheme income differences between any pair of economies are explained systematically by two types of influences; differences in values of panEuropean variables $\left(X_{1}, X_{2}, \ldots\right)$ and the pan-European parameters $\left(a_{1}, a_{2}, \ldots\right)$ that link these variables with incomes. A representation of follower $j$ 's income by a "catchup" variable, the difference in income between leader $\mathrm{i}$ and follower $\mathrm{j}$, merely uses the above equation as one explanatory term. However, since the $X_{i}$ and their parameters $a_{i}$ are not made explicit in practice, the full equation ( $1 a$ ) is not specified, the exercise remains descriptive rather than explanatory.

$$
Y_{j}=b_{1}\left(Y_{i}-Y_{i}\right)=b_{1}\left\{a_{1}\left(X_{1 i}-X_{1 i}\right)+a_{2}\left(X_{2 i}-X_{2 i}\right)+\ldots+\left(e_{i}-e_{j}\right)\right\}(1 a)
$$

Similarly, an explanation for the growth rate of economy with a "catch-up" term is equivalent to accounting for the current level of the economy's income with the lagged terms on the right hand side of equation (1) and a lagged value of that economy's income. In short it fails to expose the causes of growth.

The non-systematic part of the explanation is measured by random error terms, $e_{i}-e_{j}$ for any pair $i$ and $j$ and encapsulates country-specific influences, as well as differences in income measurement errors. In his discussion of why England experienced an industrial revolution before France, Crafts (1977) maintained the values of the relevant $\mathrm{X}$ were similar in the two countries and therefore the explanation was to be sought in the e. If history could be replicated a hundred or a thousand times then on half of these occasions, France would have been first. The problem in that instance is that we have only one observation. In the present representation, country specific influences, such as styles of government, may well

comparable inflow to India from the Roman Empire did not cause Indian capitalism, it was not the geography of European rivers (X3) and the inland sea of the Mediterranean because capitalism did not emerge under the Greek and Roman Empires. Instead it was the rational spirit which gave rise to the rational enterprise, accounting, technology and law. But we might imagine that if, say X1 and X2, or even X5, took a number of different values (they were not merely binary), then $Y$ might have been different in the rest of the world also and that the association between $Y$ and $X 4$ was merely a matter of chance or even reverse causation. 
be ultimately traceable to historical unique events which could be described as chance. But in that case the replication of history would have to cover a period of more than a century, not merely a few critical decades at the end of the eighteenth century.

A systematic understanding of nineteenth century European economic development requires an elaboration of the model of Figure 2. The structure adopted is a production function and factor supply and demand equations". In addition, variations in the quality of the labour input ('illit') and in the sectorial distribution may well have contributed to output. The production function may be thought of as disaggregated into 'traditional' ( $A$, agriculture) and 'modern' $(M$, urban or manufacturing) sectors. In Figure 3 (from Williamson (1991)), a fixed quantity of labour is divided between the demands of the two sectors. When payments match sectoral marginal productivities at $w$ then labour is distributed between sectors so as to maximise productivity. The more common position may have been where marginal productivity in the more advanced sector was higher than in agriculture, at $\mathrm{w}_{\mathrm{m}}$ and $\mathrm{w}_{\mathrm{a}}$ respectively. An increase in demand for the products of the advanced sector in this model shifts upwards that sector's demand for labour (to $D_{M 1}$ ) but only reallocates labour between the sectors if the marginal productivity gap is not allowed to widen. So long as there is such a gap, labour migration out of agriculture raises the efficiency term of the aggregate production function. Whether agricultural labour productivity was actually lower on average in Europe may then be tested, and the consequences of rallocating labour between sectors measured, by including a sectoral distribution of the labour force variable. If the terms of trade shifted against the traditional sector, because of cheaper agricultural imports for instance, the gains from shifting labour into the advanced sector are increased. When sectorial marginal productivities are equal, and there are no shifts in the terms of trade for external reasons, then there are no gains from reducing the proportion of the labour force in agriculture.

The aggregate production function strictly explains output per head of labour force. This could be calculated from output per head using the labour force participation rate to transform the population per head data. The participation rate and national labour forces are assumed exogenous in this model. Over a longer period of time than the years $1860-1910$ that would probably misleading but it could be a convenient simplification.

Let $\mathrm{R}=$ Labour Force/Population, $\mathrm{k}=\log$ of capital, $1=\log$ of labour, pop = population and illit the illiteracy index, then the production function in logarithms is

$$
\begin{aligned}
& \mathrm{q}=\alpha_{0}+\alpha_{1} \mathrm{k}+\alpha_{2}\left(1+\alpha_{3} \text { illit }\right)+\ldots \\
& \mathrm{q}-1=\alpha_{0}+\alpha_{1} \mathrm{k}+\left(\alpha_{2}-1\right) 1+\alpha_{2} \alpha_{3} \text { illit }+\ldots \\
& =\mathrm{q}-\mathrm{r}-\mathrm{pop}=\alpha_{0}+\alpha_{1} \mathrm{k}+\left(\alpha_{2}-1\right)(\mathrm{r}+\text { pop })+\alpha_{2} \alpha_{3} \text { illit }+\ldots
\end{aligned}
$$
ferable.

In practice the accuracy and availability of the data suggested output per head data would be pre- 


\section{FIGURE 3}

Agricultural Productivity and the Distribution of the Labour Force

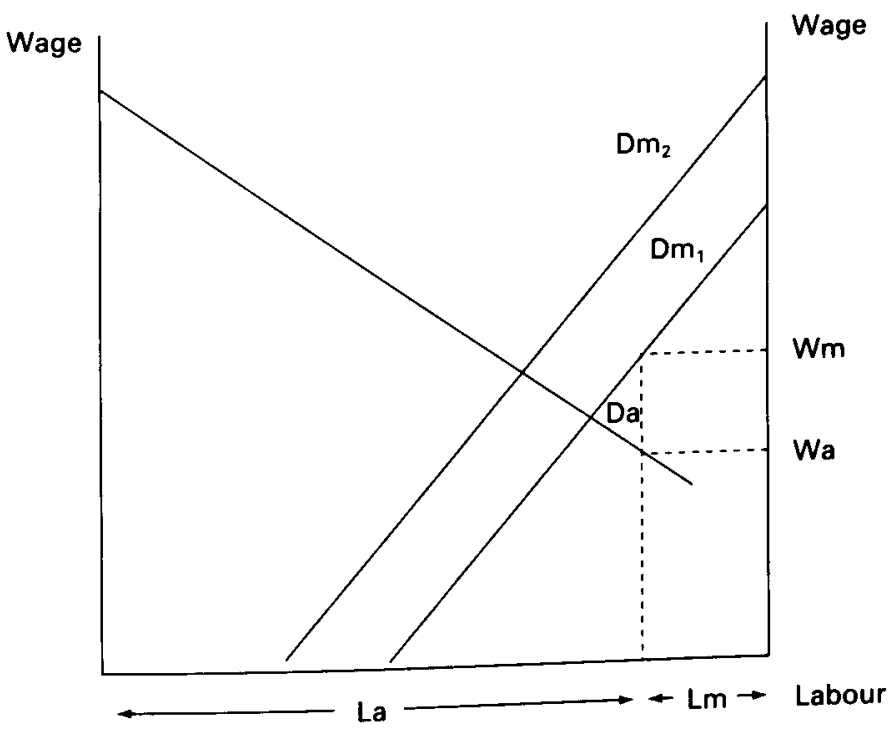

The proportion of the work force in agriculture depends upon average agricultural productivity, for that determines how much produce can be supplied to the non-agricultural sectors ${ }^{10}$. Agricultural productivity is likely to have been affected by climate. Within countries climate may vary quite markedly, as between Marseilles and Paris, but generally there are few possible historical observation points - usually national capitals - to choose from ${ }^{11}$. The variation over the year, or between say January and July, is likely to be less sensitive to the location in the country at which it is measured however, and it is this monthly difference, rather than the annual average, that is likely to matter for soil moisture. Demand for non-agricultural output pulls workers out of agriculture, while agricultural output demand holds them back. Population growth increases both agricultural demand and labour force. Thus general capital supply, infrastructure and policy variables

11) Direct measures of agricultural productivity are no less uncertain than GDP estimates. O'Brien and Prados (1992) estimate Spain's agricultural labour productivity falls between $68.1 \%$ and $106.7 \%$ of Italy's.

"Data from Smithsonian Institute (1927). 
such as tariffs will influence the sectorial distribution of the workforce. Late nineteenth century European proportions of the male force occupied in agriculture, forestry and fishing reflect the relative strengths of the opposing forces (as well as the idiosyncrasies of census classifications). Spain's agricultural labour force proportion rose between 1860 and 1877 before falling to Italian levels in 1910. Thanks to international specialisation, high income Denmark's proportion reached a maximum of $50.5 \%$ in 1896 compared with low income Portugal at $65 \%$ in 1890 and Britain's $9 \%$ by 1910 .

Turning to the other great natural resource of nineteenth century Europe, coal, if deposits were not exploited then they could not have contributed to economic growth. Production per head of population therefore is a better indicator of coal resource abundance than deposits. Known deposits are likely to depend upon the intensity of search which in turn will depend on demand. Although production depends upon infrastructure development, coal output differences between countries are not solely determined by infrastructure but also by geology and trade. Coal output per head shows Britain as an outlier, with more than double the 1910 value of her nearest rivals, Germany and Belgium. But low income Spain mined more than richer Sweden or Italy, and Austria-Hungary more than France. Trade allowed coal consumption per head in Italy by 1910 at 0.29 metric tons almost to match Spain's consumption of 0.32 metric tons.

Railways made the greatest demands upon capital and integrated national markets (O'Brien, 1982). The determinants of national railway sizes can be divided into supply and demand side influences. The demand is mainly derived from the production function. Britain was rather exceptional in the proportion of passenger traffic carried on her railways. Large countries had reason to take more advantage of railways, other things being equal, than small. Distances between population centres and natural resource locations were inevitably shorter in small countries and therefore less capital was needed in railways to join them up to create a given productivity level. Railway length is therefore deflated by area in the present model. For two countries with the same sized railway sistem, the one with the higher population density would be better served, for willingness to pay for average haul or trip lenght would be lower; the same number of people can be reached in a smaller area. Denmark, like the Netherlands, was a precocious railway builder between 1860 and 1910, overtaking Spain in the ranking, although by far the densest network at both dates was to be found in Belgium.

The area of a country is also pertinent to foreign trade, for with a given degree of specialisation, division of labour and therefore productivity, a larger economy would trade less with other nations. Controlling for country size, openness to foreign trade is a good index of productivity and income per head, but it does not 
indicate what is responsible for the income per head and therefore adds nothing to the explanation. Railways, by contrast were the means by which the market was widened and productivity boosted.

Interest rates, as a measure of capital scarcity, presuppose well-developed capital markets, which did not exist outside a few Western European economies. Instead there was the international market based in London where national government bonds traded at interest rates which tended to rise with distance eastwards. This spatial pattern depended in part on country risk, on the likelihood of exchange rate depreciation and government default, both of wich could be diminished in the eyes of the market by a credible committment to the gold standard. Guaranteeing national currency convertibility into gold markedly increased the availability of capital from abroad and reduced the cost (Gregory, 1979; MartínAceña, 1993) ${ }^{12}$. For capital exporting countries, a gold standard meant higher returns to capital than in an economy exposed to more exchange rate uncertainty. Probably of greater significance was the fiscal responsibility implied by a link of the national currency to precious metal. A gold standard government could not support excessive spending by printing money, and business confidence at home as well as abroad would have been enhanced. Gold conferred more stability than bimetallism or silver because of the preminence of gold standard Britain in world trade and the changing relative values of gold and silver after the mid-century. Bimetallic and silver countries experienced serious monetary disorders in the 1860 s and 1870 s which were likely to deter investment. These considerations suggest the length of time on the gold standard may determine how high output per head would be. But since the greater investment encouraged by the gold link will have beeen subject to diminishing returns, the impact of time on adherence will not have increased without limit ${ }^{13}$. Although richer countries were more assiduous in maintaining a gold link for their currencies, one of the poorest, Portugal adhered to the gold standard from 1854 to $1891^{14}$, and Spain only abandoned gold in 1883 , offering at least two pieces of evidence that causation did not run from income to gold standard membership.

Apart from the monetary stance, state policy varied considerably in a number of respects. Policy may have influenced the level of literacy by tax-financed schooling but it is the results of (lagged) literacy or illiteracy that we observe in this specification. Equally policy may determine the agricultural labour productivity di-

12 Adherence to the silver standard in the early part of the period may have been helpful for countries concerned to attract French capital.

13 Somewhat arbitrarily the empirical specification adopts a twenty year cut off. Other formulations,
taking a starting value of 1850 , or a binary variable, do not make a great deal of difference to the $t$ ratio.

is Communication from Jaime Reis. 
fferential, the flow of labour into the modern sector or the spread of railway networks but none of these possible effects is distinguished in the present model. By contrast some allowance is made for tariff protection, and the share of the railways owned by the state as independent influences on development. Ownership of railways, by far the largest user of capital, varied markedly across Europe by 1890 . In Germany almost all were state owned, in France almost all were private. Spanish railways were operated entirely by companies but about $40 \%$ of Italian railways were state operated. Tariff protection was particularly high in the lowest income countries, Portugal and Russia. Some of the effects of tariff protection in Portugal from 1890 might be captured by the slower transfer of labour from agriculture consequent upon the tariff influence upon the domestic intersectorial term of trade.

To estimate the model real output per head data (in 1970 US\$) on up to 18 European countries at decadal intervals from 1860 and 1910 were assembled. Some of the output per head estimates are at least as controversial as any models that might be used to explain them. While Prados (1992G) judged that in 1913 Spanish national income per head was far below Italian, Lains' (1992) survey concluded that they were very similar. There is as yet no consensus on Portugal's growth experience between 1860 and 1910 (Lains and Reis (1992)). The figures employed here for Greece were taken from Dertilis (1993) and for Romania and Bulgaria in 1913 (as an approximation to 1910) from Gini, as transmitted by Lains (1992). For the Kingdom of Austria we use Clark's estimates in (Lains (1992) Table A1). New data for Sweden (Krantz 1988) raises that country in the league markedly, while series for Spain (Prados, 1992a), and Portugal (Lains, 1989), lower the output ranking of those two economies. Italian GNP per head was taken from Prados (1992a) and Maddison (1992). Otherwise data are from Maddison (1982; 1989 Table 1.3) (Netherlands, Finland, Swizerland) and Crafts (1983) ${ }^{15}$. Inevitably there are substantial margins of errors in these estimates.

Human capital is measured by the most readily available internationally comparable measure for this period which is literacy, as indicated by the bridegroom or bride's ability to sign the marriage register. Other measures include literacy among conscripts or the general population as revealed in Census reports. Literacy data

15 Other countries included in the 18 country data set not mentioned explicity in the paragraph are Belgium, Denmark, France (port-unification), Germany, Russia, Norway, and the United Kingdom. The conversion between different bases uses the United Kingdom's output as the "numeraire". As Lains (1992) points out, this conversion may be a source of error if the United Kingdom estimate is incorrect. Crafts' output figures are for GNP whereas Maddisons are for GDP. British GDP exceeded GNP. Yet the GDP per head implied by Maddison's (1982) Table A3 and the output and population series suggest a slightly higher figure for 1910 than Crafts' $\$ 1320 .(\$ 68082 \times 0.922) / 44.916=\$ 1397$. In both cases the entire United Kingdom is the unit of observation, including Ireland. 
employed here are from Flora (1973) with linear interpolations. Literacy is an unambitious indicator of human capital but it is at least an appropriate direct index, unlike numbers of students or school teachers, whose productivity may vary with time and place. The lack of a strong simple correlation between income and literacy is helpful for the case that literacy may be treated as an exogenous rather than as an endogenous variable in this period. One difficulty is to find the correct conversion ratio between the three indices, conscript illiteracy, bride and bridegroon illiteracy and general illiteracy. Cipolla (1965) however is clear that one exists. There is also a matter of definitions. In nineteenth century Finland for instance the ability to read, although not the ability to write, was widespread (Myllantaus, 1990). Ideally a distinction would be drawn between male and female illiteracy and a range of lags tested (Núñez, 1990). None the less the general pattern is clear. Germany and Scandinavia were highly literate. The Netherlands were more literate than Belgium. England by 1870 was only a little less literate than the Netherlands and more so than France. Spain was in a worse position than Italy in 1880. In the 1890 s well over $60 \%$ of Russian recruits were illiterate whereas in Italy the figure was under $40 \%$.

\section{MODEL ESTIMATION AND IMPLICATIONS}

A good explanation should fit the above facts better than other accounts but should do so parsimoniously and in a manner consistent with knowledge of the way the European economies worked. Unfortunately a truly general model would be enormous in view of the range of possible explanatory variables in economic development and the variety of ways in which they might be related. The most general representation adopted in this experiment takes the policy variables (tariffs and gold standard membership), illiteracy as an index of human capital, population, natural resource variables (temperature and precipitation), and coal production (but not consumption) as exogenous to this (but not necessarily to another, higher level) model. Constant elasticity functional forms are assumed except in the equation for the proportion of the labour force in agriculture, which is semi-logarithmic. As a check on the possibility of spurious regression, in addition to an LM test on the regression residuals, the stability of each equation is tested by removing the richest country from the sample.

With two or three variables the production function relation explains around $75-80 \%$ of the variation in income per head among European countries for which estimates are available between 1860 and 1910 (Table 1). Although that leaves a considerable proportion to be explained by measurement error and unique indi- 


\section{TABLE 1}

\section{European Economies TSLS Regressions (Unbalanced) Panels, Decadal Data 1860-1910}

(A) Aggreate production function

$$
\begin{aligned}
& \text { gnp } / \text { pop }=7.31+0.127 \mathrm{coal}-1.183 \text { [agrilab] }-0.073 \text { illit } \\
& \begin{array}{lllll}
\text { (61.56) } & \text { (4.72) } & (-4.17) & & \\
& & (-5.59) & \mathrm{s}=0.164 & \mathrm{n}=59
\end{array} \\
& \text { gnp/pop }=7.67+0.014[\text { coal }]-2.129[\text { agrilab }]-0.070 \text { Illit } \\
& \begin{array}{lll}
(39.83) & (0.27) \quad(-4.50)
\end{array} \\
& (-4.50) \\
& \operatorname{LM}(F 3,56)=1.73 \quad \operatorname{SF}(6,50)=1.44 \quad s=0.194 \quad n=59
\end{aligned}
$$

(B) Agriculture

$$
\begin{aligned}
& \text { agrilab }=0.429-0.074[\text { rail }]+0.091 \text { tariff }+0.096 \text { tempdif }+0.074 \text { pop }-0.017 \text { UK } \\
& \begin{array}{llll}
(2.79) & (-3.79) \quad(8.46) & (2.14)
\end{array} \\
& \text { (3.58) } \quad(-8.38) \\
& \text { sse }=0.283 \quad \mathrm{LM}=3.83 \quad \mathrm{~s}=0.0718 \quad \mathrm{n}=61
\end{aligned}
$$

Excluding the U.K.

agrilab $=0.396-0.0738$ [rail] +0.0905 tariff +0.107 tempdif +0.071 pop

$$
\text { (2.36) } \quad \begin{array}{lllll}
(-3.61) & (7.94) \quad(2.15) \\
& (3.42) & & \\
& \text { sse }=0.280 \quad \mathrm{LM}=3.62 & \mathrm{~s}=0.075 \quad \mathrm{n}=55
\end{array}
$$

agrilab $=0.388-0.054$ [rail $]+0.073$ tariff +0.122 tempdif -0.025 julyrain +0.054 pop $-0.017 \mathrm{UK}$

$$
(-2.40)
$$$$
(5.15) \quad(2.56)
$$$$
(-2.45) \quad(2.52) \quad(-8.26)
$$$$
\text { sse }=0.214 \quad \mathrm{LM}=2.28 \quad \mathrm{~s}=0.070 \quad \mathrm{n}=51
$$

(C) Railways

$$
\begin{aligned}
& \text { rail }=-0.688+0.785 \text { pop }+0.193 \text { area }+0.165 \text { [coal }]+0.036 \text { gold }-0.129 \text { illit } \\
& \begin{array}{llll}
(1.39) \quad(10.14) & (2.72) \quad(2.54)
\end{array} \\
& \text { (4.27) } \quad(-3.27) \\
& \mathrm{LM}=2.35 \quad \mathrm{SF}=1.82 \quad \mathrm{~s}=0.434 \quad \mathrm{n}=71
\end{aligned}
$$

(D) Coal Consumption

$$
\begin{array}{cccccc}
\text { coal }=-6.18+0.658 & {[\text { rail }]-0.724 \text { pop }+0.191 \text { coalp }+1.242} & \text { gnp} / \text { pop } & -0.1383 \text { area } \\
(-1.67) & (2.26) & (-2.79) & (5.36) & (2.45) & \\
& (-0.96) & & & \\
& \mathrm{LM}=2.95 & \mathrm{SF}=1.42 & \mathrm{~s}=0.734 & \mathrm{n}=67
\end{array}
$$

\footnotetext{
Notes: all variables in logarithms except "agrilab" and "uk". $t$ statistics in parentheses. Square brackets indicate ins. trumental variable estimate. "gnp/pop" = gross natinal product per head in 1970 US $\$$. "agrilab" = ratio of workers in agriculture, forestry and fishing to total labour force, "rail" = length of railway line, "area" = area of country "illit" = illiteracy index, "coal" = coal consumption per head, "tariff" = average tariff (tariff revenue/import value). "tempdif" difference between mean July and January temperatures, "julyrain" = rainfall in July, "gold" = duration of adherence to the gold standard since 1850, "pop" = national population, "coalp" = coal production per heard, "uk" = uk dummy.

$L M$ is $\left[R^{2} /\{1 \cdot R)^{2}\right][(n-k) / k]$ from the regression of squared residuals on the independent variables of the equation, distributed as $F$ with $k$ and $n \cdot k$ degrees of freedom, where $k$ is the number of independent variables.

Structural break test $F$ test, $S F(1, n-k)=\left[\left(s^{*} e^{*}\right.\right.$-sse $\left.) / s s e\right] .[(n-k) / 1]$ distributed as $F(1, n-k)$ under the null of no break, where 1 is the number of observations added or dropped and sse* is the error sum of squares of the full sample $n+1$ and sse is for only $n$ observations.
} 
vidual countries institutions or policies, it is quite satisfactory compared with the fit of empirical models of more recent economic performance. Illiteracy lagged a decade is intended to capture human capital effects. Railways exercised no direct effect on output, once possible endogeneity was allowed for. The proportion of the male labour force in agriculture measures the impact ot the dual economy, which is rather strong. A fall in the agricultural proportion of the workforce from say $60 \%$ to $50 \%$ raises output per head by $(\exp (2.13 \times 0.1)=) 23.7 \%$.

The direct effect of coal consumption on production is significant when it is (inappropriately) assumed exogenous in estimating the function. But the impact is very small (the elasticity is. 014), and the coefficient is not significantly different from zero at the $95 \%$ level of probability when the variable was assumed to be endogenous.

Turning to the factor equations, larger railway networks lower the proportion of the workforce in agriculture, both by integrating markets and proxying the growth of industrial capital. Tariff protection does the opposite, encouraging inefficiency in resource allocation. Wide variations in temperature during the agricultural year and low soil moisture impose burdens on agriculture that keeps productivity low, thus raising the workforce proportion employed. Lower soil moisture because of low July rainfalls imposes a comparable penalty. Even allowing for different railway penetration per head of population, climate and tariff policy, structural break tests showed the necessity for distinguishing the legacy of early market relations in British agriculture.

Abundance of coal both creates a need for railways and industrial capital while at the same time providing the raw materials necessary for their cheap supply. Membership of the gold standard guaranteed cheap and secure finance and low illiteracy ensured the necessary human capital essential to the capital goods industries.

Coal consumption per head rose more than proportionately with GNP per head, because of prevailing technology. The coefficient of coal production, at 0.191 , indicates that international trade was important in compensating for the lack of coal endowments. A difference in coal production per head between countries of $50 \%$ was associated with only a 10 per cent difference in consumption, other things being equal. Transport from the coal producing areas must have raised coal prices in the consuming areas without coal but, judging by the consumption effect, not apparently by a great deal.

The empirical model of later nineteenth century economic development comprises four equations. In order to explain income differences between countries and assess counterfactual possibilities the system must be solved to yield equations in which only predetermined variables explain the endogenous variables. The relation between the structural and the reduced form equations, where $\mathrm{Y}$ and $\mathrm{Z}$ are respec- 
tively the vectors of endogenous and predetermined variables, $B$ and $\Gamma$ respectively the coefficient matrices of endogenous and predetermined variables, and $\mathrm{U}$ and $\mathrm{V}$ are error term vectors, may be represented in matrix notation as follows;

$B Y+\Gamma Z=U \ldots(2)$ the structural system (see Appendix)

$Y=-Z^{-1} \Gamma B+V \ldots$ (3) the reduced forms.

The principle focus of the present paper is on only one row of the system (3), that explaining national output per head. But as (2) and (3) make apparent, in general that may depend upon all other equations and variables in the system. The structure of model is shown in Figure 4. It could be inferred from a selective reading of the literature on European economic development in the later nineteenth century, but the presentation here has the advantage of being systematically related to the available facts.

\section{FIGURE 4}

The Model Structure

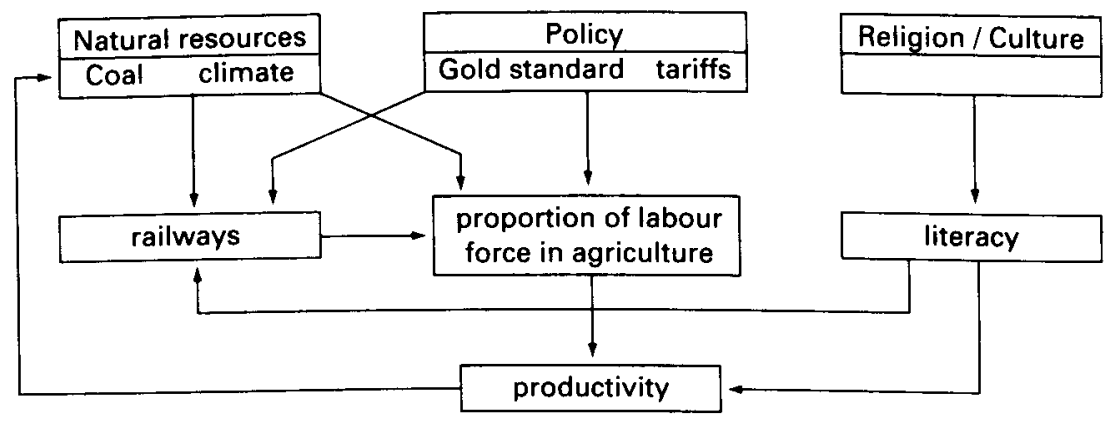

Errors in the measurement of the explanatory variables may requires the parameter values be interpreted with some caution since they may be biased. Subject to that proviso, we can examine the properties of the model by simulating it, to show how a poorly performing nineteenth century European economy, such as Spain, would have developed by 1910 if it had adopted one by one, the policies of the leader economy, Britain, the human capital and the natural resources (Table 2). There are two alternative paths; one is to use the reduced form implied by the structural equations, the other is to 'retrodict' with a reduced form estimated directly. The two approaches should offer some check on the appropriateness of the model ${ }^{16}$.

16 Because the correlation between logarithm of population and labour force was 0.989 , only population was used as an instrumental variable and as predetermined variable in the directly estimated reduced form equation for output, although both were assumed exogenous. 


\section{TABLE 2}

Proportionate increase in Spanish GNP per head in 1880 and 1910 if Spain achieved UK values of exogenous variables

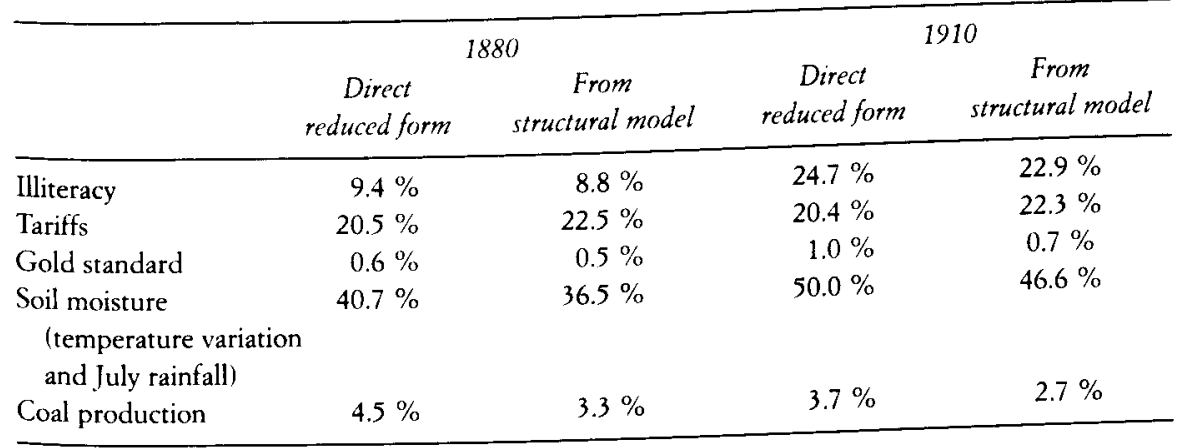

Notes: Calculated by exponentiating the difference between values of logged variables for UK and Spain multipled by regression coefficients. The impact of the gold standard depends critically upon whether duration on the standard matters (and persists), assumed here, or on whether there was a once and for all impact. In the second case the effect becomes comparable to the tariff.

Although the theoretically correct specification is to explain output per worker, both in the aggregate production function and in the reduced form equation, the loss of degrees of freedom and the difficulties of identifying and standardising workers implied that GNP per head of population was in practice a preferable variable.

The reduced form GNP per head (see Appendix) implied by the structural equations in logs is:

$$
\begin{gathered}
\text { gnp/pop }=-0.106 \text { illit }-0.212 \text { Tariff }+0.008 \text { Gold }-0.577 \text { Tempdif }+0.010 \\
\text { Coalprd }-0.045 \text { Area }+0.015 \text { Pop }
\end{gathered}
$$

Directly estimated reduced forms are:

$$
\begin{aligned}
& \text { gnp/pop }=-0.121 \text { illit }-0.173 \text { Tariff }+0.007 \text { Gold }-0.384 \text { Tempdif }+0.022 \text { Coalprd }- \\
& (-7.87) \\
& (-4.09) \\
& -0.013 \text { area }+0.012 \text { Pop. } \\
& (-0.35) \\
& \text { (0.32) } \\
& \mathrm{n}=67 \mathrm{R}^{2}=0.77 \mathrm{LM}=1.78
\end{aligned}
$$

Structural break $F$ test for exclusion of the $U K F=2.32, F_{0.01}^{c}(6,54)=3.15$. 


$$
\begin{aligned}
& \text { gnp/pop }=-0.121 \text { illit }-0.176 \text { tariff }+0.007 \text { gold }-0.215 \text { tempdif }+0.016 \text { coalprd }- \\
& \begin{array}{llll}
(-8.71) & (-4.59) \quad(2.00) \quad(-1.85)
\end{array} \\
& -0.025 \text { area }+0.010 \text { pop }+0.018 \mathrm{UK} \\
& (-0.72) \quad(0.28) \quad(3.70) \\
& \mathrm{n}=67 \mathrm{LM}=1.84 \mathrm{R}^{2}=.834
\end{aligned}
$$$$
\text { gnp/pop }=-0.099 \text { illit }-0.150 \text { tariff }+0.007 \text { gold }-0.253 \text { tempdif }+0.064 \text { julyrain }+
$$$$
\begin{array}{llll}
(-6.58) & (-3.58) \quad(1.99) \quad(-2.13)
\end{array}
$$$$
+0.010 \text { coalprd }-0.028 \text { area }+0.019 \text { pop }+0.017 \mathrm{UK}
$$$$
\begin{array}{llll}
(0.97) & (-0.73) & (0.52) & \text { (3.32) }
\end{array}
$$

$$
\mathrm{n}=56 \mathrm{R}^{2}=.85 \mathrm{R}^{2}=.82 \mathrm{LM}=1.42
$$

The reduced form illiteracy elasticity of output per head or worker is around 0.1 . The coefficient on the gold standard of .007-008 implies little output gain from adhering to the gold standard (but the apparent gain is large if a binary measure, instead of a duration related specification, is adopted). The soil moisture proxy, temperature variation, elasticity is large, between 0.21 and 0.58 , and the upper end of the range is favoured when the July rainfall measure supplements temperature difference. The coal production elasticity is invariably small, around $0.01-0.02$, in contradiction to those accounts that regard the presence or absence of coal deposits as central to nineteenth century economic development. The UK dummy captures the historical legacy that contributed to the low proportion of labour in the agricultural sector by the beginning of the period.

There are two reasons why the model does not fit the data exactly and therefore why it does not predict precisely the output per head of later nineteenth century Spain or Britain; errors in the measurement of output and unique national policies or characteristics. However a comparison can be made independently of these unique influences by calculating the contributions of the exogenous variables to the Spanish-UK output differential (Table 2). Since country characteristics may be positive or negative, even if Spain adopted UK values for all exogenous variables in the model the differential would not be exactly explained; it may be over-or under-determined depending upon the net impact of the two country-specific factors.

The five variables account for rather more than half of the measured difference in output per head of population in 1880 . The remainder of the Spanish-UK differential is left to be explained by institutions, policies and other characteristics not captured by this model, as well as by measurement errors. Country-specific cha- 
racteristics include those factors, captured by the UK dummy that reduced the British workforce in agriculture so much more than in the rest of Europe by 1860 . The two approaches both indicate that nineteenth century liberal economic policies, represented by low tariffs (but not a more persistent committment to the gold standard) would have raised output per head by about one fifth (Spain was on the gold standard from 1877 until 1883). Natural resources, as measured in the present model, were of greater importance. Coal and weather gave Britain a 40 or 45 per cent advantage over Spain in 1880, but climate had ten times the impact of geology. The cultural inheritance as captured by literacy rates mattered much less in 1880. Perhaps Spain would have gained an extra one tenth of output per head with British levels of literacy. Further investigation with longer lags and literacy disaggregated between males and females (Núnez, 1990) may change this result however.

By 1910 liberal economic policies no longer dominated the sources of the output gap. The contribution of the literacy gap more than doubled and the climatic handicap increased, while the proportionate impact of differential tariff policies on the income gap remained unchanged.

\section{CONCLUSION}

The preceding section suggests a causal pattern of nineteenth century European economic development. The model is both simple and sufficiently general to encompass a number of earlier explanations. With so many countries and so many possible relevant variables, the direct processing limitations of the mind require support from formal methods to sort the specifications that fit historical experience from those that do not. Simplicity, rather than exhaustive descriptive accuracy, is essential to address the range of economic data generated by nineteenth century Europe. At the same time the model offers a partial account of why there were leader and follower economies and the sources of catching up and falling behind, rather than merely describing the pattern. By identifying the relative contribution of variables to output per head, the model allows a distinction between equally attractive alternative, and inferior, roads to development. At the same time the approach can cast light on a variety of apparently competing explanations; those based on politics, on institutions, on coal and on literacy. Liberal economic policies (low tariffs) are clearly associated with stronger economic performance, and may be even more pervasive. These findings are consistent with Mulhall's (1881) more specific conclusions about the Spanish economy around 1880;

"It would be only necessary to sell or emancipate her colonies, dismiss one half of the public employees and renounce the system of persecuting foreign vessels in 
Spanish ports: then Spain would rapidly rise in the scale of nations from her present low rank" 17 .

The emphasis on economic liberalism does not preclude a contribution from literacy. Despite the ubiquity of coal as a source of energy and heat, possession of substantial coal deposits mattered little for economic development, but climate mattered a great deal. Judging by the proportion of output per head not accounted for by the model, national institutions and other (non-tariff and gold standard) policies retain a large role in explanations of nineteenth century development, but one whose magnitude is potentially less precise ${ }^{18}$.

Because the parameter estimation is probabilistic, the conclusions do not require the national output measures be free from errors, nor is the model proposed here anything more than a beginning. That the units of observations are not internally homogenous does not invalidate the exercise. All that is required is that differences between national economies be greater than those within, a condition that is suggested by the long term consequences of national policies, institutions and culture, which have shaped nationally distinctive European economic styles. Undoubtedly more precise indicators of both dependent and independent variables are necessary; regional indicators could greatly improve the data set. There is a danger that some important variables, such as general taxation per head, are excluded from the model because their measures are too imperfect rather than because they lack explanatory power. But to ignore what is currently available is to fail to recognise the provisional nature of all scientific results.

Summarising the qualitative conclusions, the proximate determinants of output per head differences between European countries and over the years 1860 and 1910 confirm the role of the dual economy, of climate, of economic liberalism and of human capital. Railways and physical capital were influenced by whether a country was on the gold standard or not and by national coal endowment. The proportion of the work force in agriculture, reflecting agricultural productivity, depended upon tariff protection and soil moisture. So in the present model the ultimate determinants of European nations' output per head were climate, tariff protection, very marginally the gold standard, coal and literacy, together with other country specific factors and perhaps variables not considered in this analysis. The background conditions of the model and the

${ }^{17}$ Mulhall felt the same policy of liberalisation was needed for Portugal; “... incidence of taxation is overwhelming... Military expenditure is enormous... It might be reduced by giving up such useless possessions as Mozambique and Goa."

18 Other, higher level, models may subsume the present attempt. So in a more general structure, economic policies may be endogenous; membership of the gold standard may be explained by lagged economic or current political variables for instance. In the limit the more general model might depend only on past unique events and it becomes akin to path dependent, or non-ergodic, growth models. 
counterfactuals it supports are the state of technology, society and institutional environment of later nineteenth century Europe. More generally the contribution of nineteenth century liberal policies for economic development among systematic influences seem to be confirmed, coal is demoted and soil moisture appears as a key determinant.

\section{APPENDIX}

\section{The Model}

$\mathrm{By}+\mathrm{\Gamma z}=\mathrm{U}$

$$
\left[\begin{array}{rrrr}
-1 & \beta_{1} & \beta_{2} & 0 \\
0 & -1 & 0 & \tau_{1} \\
\theta_{1} & 0 & -1 & \theta_{2} \\
0 & 0 & \phi_{1} & -1
\end{array}\right]\left[\begin{array}{l}
\text { GPN/POP } \\
\text { Agrilab } \\
\text { Coal } \\
\text { Rail }
\end{array}\right]+\left[\begin{array}{llllllll}
\beta_{1} & 0 & 0 & 0 & 0 & 0 & 0 & 0 \\
0 & 0 & \tau_{2} & \tau_{3} & 0 & \tau_{4} & \tau_{5} & 0 \\
0 & \theta_{3} & \theta_{4} & 0 & 0 & 0 & 0 & \theta_{5} \\
\phi_{2} & \phi_{3} & \phi_{4} & 0 & \phi_{5} & 0 & 0 & 0
\end{array}\right]\left[\begin{array}{l}
\text { Illit } \\
\text { Area } \\
\text { Pop } \\
\text { Tariff } \\
\text { Gold } \\
\text { Tempdif } \\
\text { Julyrain } \\
\text { Coalp }
\end{array}\right]
$$

from the coefficients of table 1 . For key to variables see notes to Table 1.

$$
\begin{array}{rrrr}
\multicolumn{4}{c}{\mathrm{B}=} \\
-1.000 & -2.129 & 0.014 & 0.000 \\
0.000 & -1.000 & 0.000 & -0.054 \\
1.242 & 0.000 & -1.000 & 0.658 \\
0.000 & 0.000 & 0.165 & -1.000
\end{array}
$$$$
-r=
$$

$\begin{array}{rrrrrrrr}0.070 & 0.000 & 0.000 & 0.000 & 0.000 & 0.000 & 0.000 & 0.000 \\ 0.000 & 0.000 & -0.054 & -0.073 & 0.000 & -0.122 & 0.025 & 0.000 \\ 0.000 & 0.138 & 0.724 & 0.000 & 0.000 & 0.000 & 0.000 & -0.191 \\ 0.129 & -0.193 & -0.785 & 0.000 & -0.036 & 0.000 & 0.000 & 0.000\end{array}$

$$
-\mathrm{B}^{-1} \Gamma=
$$

$\begin{array}{llllllll}-0.092205 & 0.022830 & -0.033950 & -0.162900 & 0.005256 & -0.272244 & 0.055788 & 0.007404\end{array}$

$\begin{array}{llllllll}0.008959 & -0.010595 & 0.014105 & 0.075022 & -0.002246 & 0.125380 & -0.025693 & -0.002001\end{array}$

$\begin{array}{llllllll}-0.223687 & 0.019462 & -0.280040 & -0.226963 & 0.033896 & -0.379308 & 0.077727 & 0.224579\end{array}$

$\begin{array}{llllllll}-0.165908 & 0.196211 & 0.738793 & -0.037449 & 0.041593 & -0.062586 & 0.012825 & 0.037055\end{array}$ 


\section{REFERENCES}

Azzi, G. (1956): Agricultural Ecology, London, Constable.

BAIROCH, P. (1976): "Europe's Gross National Products: 1800-1975", Journal of European Economic History, 5, pp. 273-340.

BARRo, R. J. and X. Sala-i-Martin (1992): "Convergence", Journal of Political Economy, 100, pp. $223-251$.

BARRO, R. J. (1991): “Economic Growth in a Cross-section of Countries", Quarterly Journal of Economics, 106, pp. 407-43.

BAUMOL, W. J. (1986): "Productivity Growth, Convergence and Welfare: What the Long Run Data Show", American Economic Review, 76, pp. 1072-85.

CAMERON, R. (1985): “A New View of European Industrialisation”, Economic History Review, 38, pp. 1-23.

Cameron, R. E. (1989): A Concise Economic History of the World, New York and London, Oxford University Press.

CARON, F. (1979): An Economic History of Modern France, London, Methuen.

Chandler, A. (1990): Scale and Scope: The Dynamics of Industrial Capitalism, Cambridge, Mass., Belknap Press of Harvard University.

Chenery, H. B. and Syquin, M. (1975): Patterns of Development 1950-1970, London, Oxford University Press.

CipOlLA, C. (1965): Literacy and Development in the West, Harmondsworth, Middlesex, Penguin.

Crafts, N. F. R. (1977): "Industrial Revolution in England and France: Some Thoughts on the Question, 'Why was England First?", Economic History Review, 30, pp. 429-441.

- (1983): "Gross National Product in Europe 1870-1910, Some New Estimates", Explorations in Economic History, 20, pp. 387-401.

- (1984): "Patterns of Development in Nineteenth Century Europe", Oxford Economic Papers, 36, pp. 438-458.

- (1985): British Economic Growth during the Industrial Revolution, Oxford, Clarendon Press.

DeLonG, B. (1989): "Productivity Growth, Convergence and Welfare; Comment", American Economic Review, 79, pp. 1138-59.

Dertilis, G. (1993): Atelesforoi i telesforoi? Taxes and Political Power in Modern Greece, Athens, Alexandreia Press.

Dowrick, S. (1992): "Technological Catch up and Diverging Incomes: Patterns of Economic Growth 1960-1988”, Economic Journal, 102, pp. 600-610.

DOwrick, S. and Gemmel, N. (1991): "Industrialisation, Catching Up and Economic Growth: a Comparative Study Across the World's Capitalist Economies", Economic Journal, 101, pp. 263-75.

Elbaum, B. and LAZONICK, W., eds. (1986): The Decline of the British Economy, Oxford, Clarendon Press.

Feinstein, C. H. and Pollard, S. (eds.) (1988): Studies in Capital Formation in the UK, 1750-1920, Oxford, Clarendon Press.

FLORA, P. (1973): "Historical Processes of Social Mobilization: Urbanisation and Literacy 1850-1965", in S. N. Eisenstadt and S. Rokken, eds., Building States and Nations: Models and Data Resources, vol. 1, Beverly Hills, Sage.

GersChEnKRON, A. (1966): Economic Backwardness in Historical Perspectives, Cambridge Mass., Belknap. 
GiLberT, C. L. (1986): "Professor Hendry's Methodology”, Oxford Bulletin of Economics and Statistics, 48, pp. $213-228$.

Gregory, P. R. (1979): "The Russian Balance of Payments, the Gold Standard and Monetary Policy", Journal of Economic History, 39, pp. 379-99.

- (1982): Russian National Income 1885-1913, Cambridge, Cambridge University Press.

Jevons, W. S. (1906): The Coal Question, London, Macmillan.

JONES, E. L. (1981). The European Miracle: Environments Economics and Geopolitics in the History of Europe and Asia, Cambridge, Cambridge University Press.

- (1988): Growth Recurring: Economic Change in World History, Oxford, Clarendon Press.

Kennedy, W. P. (1987): Industrial Structure, Capital Markets and the Origins of British Economic Decline, Cambridge, Cambridge University Press.

Kindleberger, C. P. (1964): Europe's Post-War Growth: The Role of Labour Supply, Oxford University Press.

KRANTZ, O. (1988): "New Estimates of Swedish Historical GDP since the Beginning of the Nineteenth Century", Review of Income and Wealth, 34, pp. 215-42.

LAINS, P. (1989): "Modern Economic Growth in Nineteenth Century Portugal", European University Institute, mimeo.

- (1992): "Looking for Third Europe", unpublished.

- and Reis, J. (1991): "Portuguese Economic Growth 1833-1985: Some Doubts", Journal of European Economic History, 20, pp. 441-453.

Landes, D. S. (1970): The Unbound Prometheus, Cambridge, Cambridge University Press. LeVy-Leboyer, M. and BOURGignon, F. (1990): The French Economy in the Nineteenth Century: An Essay in Econometric Analysis, Cambridge, Cambridge University Press.

Madison, A. (1982): Phases of Capitalist Development, Oxford and London, Oxford University Press.

- (1992): "El crecimiento economico italiano 1861-1989 una revision", in L. Prados de la Escosura and V. Zamagni, eds., El desarrollo económico en la Europa del Sur: España e Italia en Perspectiva Histórica, Madrid, Alianza Universidad.

Mankiw, N.; Gregorr, D.; Romer, D.; WeIL, N. (1993): "A Contribution to the Empirics of Economic Growth”, Quarterly Journal of Economics, 108, pp. 407-437.

MaRTÍN-ACENA, P. (1993): "Spain During the Classical Gold Standard Years, 1880-1914", in M. D. Bordo and F. Capie, eds., Monetary Regimes in Transition, Cambridge, Cambridge University Press.

MeYer, S. (1981): The Five Dollar Day, New York, New York State University Press.

Milward, A. and SaUL, S. B. (1973): The Economic Development of Continental Europe 1780-1870, London, Allen and Unwin.

- (1977): The Development of the Economies of Continental Europe 1850-1914, London, Allen and Unwin.

Mitchell, B. R. (1980): Abstract of European Historical Statistics, London, Macmillan, 2nd ed.

Molinas, C. and Prados de la Escosura, L. (1989): "Was Spain Different? Spanish Historical Backwardness Revisited", Explorations in Economic History, 26, pp. 385-402. Morris, C. T. and Adelman, I. (1988): Comparative Patterns of Economic Development 1850-1914, Baltimore, John Hopkins University Press.

Mulhall, M. G. (1881): Balance Sheet of the World for Ten Years, London.

Myllantaus, T. (1990): "Education in the Making of Modern Finland", in G. Tortella, ed., 
Education and Economic Development Since the Industrial Revolution, Valencia, Generalitat Valenciana.

NeLSON, R. R. and G. WRIGHT (1992): "American Technological Leadership", Journal of Economic Literature, 30, pp. 1931-64.

NORTH, D. C. (1981): Structure and Change in Economic History, New York and London, Norton.

NÚÑEz, C.-E. (1990): "Literacy and Economic Growth in Spain", in G. Tortella, ed., Education and Economic Development Since the Industrial Revolution, Valencia, Generalitat Valenciana.

O'BriEn, P. K. (1986): "Do We Have A Typology for the Study of European Industrialization in the Nineteenth Century?", Journal of European Economic History, 15, pp. 291-333.

- and Prados DE LA Escosura, L. (1992): "Agricultural Productivity and European Industrialisation 1890-1980", Economic History Review, 45, pp. 514-36.

-, ed. (1982), Railways and the Economic Development of Europe 1830-1914, London, Macmillan.

- and KEYDER, C. (1978): Economic Growth in Britain and France 1780-1914: Two Paths to the Twentietb Century, London, Allen and Unwin.

Olson, M. (1982): The Rise and Decline of Nations: Economic Growth Stagflation and Social Rigidities, New Haven, Yale University Press.

PENCAVEL, J. H. (1977): "The Efficiency and Distributional Effects of Trade Unions in Britain", British Journal of Industrial Relations, 15, pp. 137-156.

PLATT, D. C. M. (1984): Foreign Finance in Continental Europe and the USA 1815-1870: Quantities, Origins, Functions and Distribution, London, George Allen \& Unwin.

POLLARD, S. (1981): Peaceful Conquest: The Industrialisation of Europe 1760-1970, Oxford, Oxford University Press.

PRADOS DE LA EsCOSURA, L. (1992): "Crecimiento, atraso y convergencia en España e Italia: introducción", in L. Prados de la Escosura and V. Zamagni, eds., El desarrollo económico en la Europa del Sur: España e Italia en Perspectiva Histórica, Madrid, Alianza Universidad.

RosenBerg, N. and L. E. Birdzell (1986): How the West Grew Rich: The Economic Transformation of the Industrial World, New York, Basic Books.

Rostow, W. W. (1960): The Stages of Economic Growth: A Non-Communist Manifesto, Cambridge, Cambridge University Press.

SANDBERG, L. (1982): "Ignorance, Poverty and Economic Backwardness in the Early Stages of European Industrialization: Variations on Alexander Gerschenkron's Grand Theme", Journal of European Economic History, 11, pp. 675-97.

Smithsonian Institute (1927): World Weather Records, Miscellaneous Collection, 79, Washington.

SLICHER VAN BATH, B. H. (1963): The Agrarian History of Western Europe AD 500-1850, London, Edward Arnold.

STUDENSKI, P. (1958): The Income of Nations: Theory Measurement and Analysis Past and Present, New York, New York University Press.

Sylla, R. and TONIOLO, G., eds. (1992): Patterns of European Industrialization: The Nineteenth Century, London, Routledge.

TORTELLA, G. (1994): "Patterns of Retardation and Recovery in South-western Europe in the Nineteenth and Twentieth Centuries", Economic History Review, 47, pp. 1-21. 
WEBER, M. (1961): General Economic History, New York.

Wilkins, M. and F. F. Hill (1964): American Business Abroad: Ford on Six Continents, Detroit, Wayne State University Press.

Williamson, J. G. (1991): “Did English Factor Markets Fail During the Industrial Revolution?", in N. F. R. Crafts, N. H. Dimsdale and S. Engerman, eds., Quantitative Economic History, Oxford, Clarendon Press.

Yoshimuri, M. (1988): "Catholicism and Anti-Business Bias: The Case of France", International University of Japan Annual Bulletin, 5, pp. 107-131. 